\title{
Comparison of the prophylactic effect of dexamethasone and dexmedetomidine and their combination in reducing postoperative nausea and vomiting in patients undergoing laparoscopic cholecystectomy
}

Siamak Rekei ${ }^{1}$, Amir Reza Naeimi ${ }^{1}$, Behnam Mahmodiyeh ${ }^{2}$, Roya Golmoradi ${ }^{~}$, Alireza Kamali ${ }^{2 *}$

\section{Author Affiliations:}

1. Department of Surgery, Arak University of Medical Sciences, Arak, Iran

2. Department of Anesthesiology and Critical Care, Arak University of Medical Sciences, Arak, Iran

\section{ABSTRACT}

Nausea and vomiting are some of the most common complaints of patients after any anesthesia, which is often associated with postoperative pain. The double-blind clinical trial study aimed to compare the prophylactic effect of dexamethasone and dexmedetomidine and their combination in reducing postoperative nausea and vomiting in patients undergoing laparoscopic cholecystectomy. One hundred sixty-two patients undergoing laparoscopic cholecystectomy were enrolled in the study. In the first group of patients, $25 \mathrm{mg}$ of dexmedetomidine were administered slowly. In comparison, the patients in the second group received dexamethasone $(4 \mathrm{ml} / 2 \mathrm{mg}$ ) with $0.1 \mathrm{mg} / \mathrm{kg}$ of normal saline solution. The third group received a combination of dexmedetomidine and dexamethasone. Hemodynamic changes were recorded during surgery and after surgery, and the patients were admitted to recovery. Nausea and vomiting scores were recorded 2 and 4 hours after surgery. Blood pressure and heart rate were lower in the dexmedetomidine group at all times $(\mathrm{P}<0.05)$. Two hours after surgery, the dexamethasone and dexmedetomidine combination group had less vomiting $(\mathrm{P}=0.012)$. The incidence of nausea 2 and 4 hours after surgery was lower in the dexamethasone and dexmedetomidine combination group $(\mathrm{P}<0.05)$. Blood pressure and heart rate were lower in the dexmedetomidine group at all times. The dexmedetomidine and dexamethasone combination decreased postoperative nausea and vomiting in patients. Therefore, we recommend using a dexmedetomidine and dexamethasone combination for reducing postoperative nausea and vomiting.

KEYWORDS: dexmedetomidine, dexamethasone, vomiting, nausea, laparoscopy.

\author{
* Corresponding Author: \\ Alireza Kamali, Department of Anesthesiology and \\ Critical Care, Arak University of Medical Sciences, \\ Arak, Iran. \\ Phone: 00989125280734; \\ E-mail: change to alikamaliir@yahoo.com
}

DOI

10.25122/jml-2020-0030

\section{Dates}

Received: 12 February 2021

Accepted: 9 April 2021

\section{INTRODUCTION}

Nausea and vomiting are some of the most common complaints of patients after any anesthesia, which is often associated with postoperative pain [1]. Postoperative nausea and vomiting may occur up to 24 hours after surgery, occurring in 20-30\% of patients [2]. This may be due to the effect of anesthetics on the vomiting control center in the medulla oblongata or because of a decrease in intraoperative 


\section{JOURNAL of MEDICINE and LIFE}

hypoxia which subsequently causes nausea and vomiting. In Germany, every year, 8 million surgeries are performed, about 2.4 million people suffer from postoperative nausea and vomiting (PONV). Postoperative nausea and vomiting can cause complications such as airway obstruction, aspiration pneumonia, and surgical wound opening [3, 4]. Postoperative vomiting causes dehydration, electrolyte abnormalities, hypertension, suture stretching, increased bleeding from skin flaps, and delayed discharge. This complication can increase the risk of pulmonary aspiration if the airway reflexes are reduced due to the residual effects of anesthetic drugs [2]. To date, several drugs, including dopamine and serotonin receptor antagonists, corticosteroids, antihistamines, sedatives and anticholinergics, have been used to treat this disorder [5-7]. The most common drugs to relieve nausea and vomiting are metoclopramide and droperidol. Due to complications such as fatigue and restlessness, lack of awareness of time and place, extrapyramidal symptoms, cardiovascular complications, hypotension, orthostatic hypotension, drowsiness, akathisia, elevated liver enzymes, and agranulocytosis, these agents have been limited in some cases [8]. Nowadays, new therapies have replaced the above-mentioned drugs, such as drug therapy and complementary therapies, to be used as a stand-alone treatment or in combination with standard treatments [6]. Dexmedetomidine, a potent alpha-2-adrenergic receptor agonist, has been widely used due to its anxiolytic, sedative, analgesic, sympatholytic, and hemodynamic regulation properties [9]. During surgery, dexmedetomidine can reduce the incidence of restlessness and provide an acceptable recovery. It also reduces postoperative pain without hemodynamic complications. It can prevent postoperative nausea and vomiting [9], and numerous studies have shown the anti-nausea and vomiting effects of low-dose dexmedetomidine [10-12]. Dexamethasone is a corticosteroid drug that reduces inflammation and weakens the immune system [13, 14]. Dexamethasone is a cheap and available drug that is used to control postoperative nausea and vomiting $[15,16]$. During the last two decades, the anti-nausea and vomiting effects of dexamethasone have been shown in patients undergoing chemotherapy. Based on these findings, anesthesiologists' intention to use dexamethasone to reduce the incidence and severity of postoperative nausea and vomiting has been investigated [17, 18]. The results indicate a positive role of dexamethasone in reducing nausea and vomiting in different population groups. Although most studies on postoperative nausea and vomiting have been performed under general anesthesia, however, in other population groups, dexamethasone has been shown to reduce the incidence of nausea and vomiting [19-21]. Dexamethasone is an effective drug for nausea and vomiting, whose exact mechanism of preventing nausea and vomiting is still unknown. However, dexamethasone probably decreased postoperative nausea and vomiting by inhibiting prostaglandins [22, 23].

Since there is no study comparing these effective drugs in preventing nausea and vomiting so far, dexmedetomidine has other useful properties besides decreasing nausea and vomiting and can be a good alternative to other drugs. This study aimed to compare the prophylactic effect of dexamethasone and dexmedetomidine and their combination in reducing postoperative nausea and vomiting in patients undergoing laparoscopic cholecystitis.

\section{MATERIAL AND METHODS}

This was a double-blind clinical trial. We included all laparoscopic candidates who gave informed consent, ASA Class I and II patients, those with no history of psychotic illnesses, no Parkinson's disease, motion disorder, or history of chemotherapy, patients under general anesthesia, patients aged 18-60 years, and a maximum surgical duration of 150 minutes. Exclusion criteria included patients who have not given their informed consent to be included in the study, patients with Parkinson's disease, psychotic illnesses, or those who had a history of chemotherapy. All patients were enrolled in the study after obtaining informed consent and entered the operating room after anesthesia confirmation. For these patients, oxygen saturation (SPO2), pulse rate (PR), blood pressure (BP), non-invasive blood pressure (NIBP), and body temperature were recorded. All patients were given 3-5 ml $/ \mathrm{kg}$ of crystalloid fluid as compensatory volume expansion and the patients underwent general anesthesia. All patients received $2 \mathrm{mg} / \mathrm{kg}$ of fentanyl, $0.3-0.5 \mu \mathrm{g} / \mathrm{kg}$ of midazolam, $0.5-0.7 \mu \mathrm{g} / \mathrm{kg}$ of atracurium, and 2-3 mg/ $\mathrm{kg}$ of propofol and underwent general anesthesia.

After patient intubation, endotracheal fixation, and hemodynamic stabilization, and prior to surgical excision, $25 \mu \mathrm{g}$ of dexmedetomidine (Hospira, United States of America) were administered to patients in group I. Patients in group II were administered dexamethasone (Alborz Darou, Iran) $(4 \mathrm{ml} / 2 \mathrm{mg}$ ) with $0.1 \mathrm{mg} / \mathrm{kg}$ solution of normal saline and a total volume of $20 \mathrm{ml}$. The third group received a mix of dexmedetomidine and dexamethasone.

\section{Table 1. Vomiting score.}

\begin{tabular}{l|l}
$\begin{array}{l}\text { Vomiting } \\
\text { score }\end{array}$ & \multicolumn{1}{c}{ Description } \\
\hline $\mathbf{0}$ & No vomiting or any similar symptoms \\
\hline $\mathbf{1}$ & Mild yaw that is manageable \\
\hline $\mathbf{2}$ & $\begin{array}{r}\text { Moderate yawning and vomiting } 1 \text { to } 2 \text { times, } \\
\text { which is manageable }\end{array}$ \\
\hline $\mathbf{3}$ & Frequent yawning and vomiting, which is difficult to control \\
\hline $\mathbf{4}$ & Uncontrollable, recurrent vomiting \\
\hline
\end{tabular}

After the surgery was completed and patients were admitted to recovery, questionnaires that included questions about their nausea and vomiting score (Table 1) and their hemodynamics were distributed to all patients. Finally, the data obtained from the questionnaires were analyzed using the Statistical Package for the Social Sciences (SPSS) software, version 23.

To blind the drug product, the anonymous syringe was drawn by an anesthesiologist and was given to the surgical resident, who then gave the injection to patients. Neither surgery residents nor patients knew in which groups they were assigned. 


\section{JOURNAL of MEDICINE and LIFE}

\section{RESULTS}

This study was a double-blind clinical trial that included 164 candidates for laparoscopic surgery in Valiasr Hospital, Arak. The patients were randomly divided into three groups. The minimum age was 33 years, and the maximum age was 60 years. The mean age was $49.31 \pm 7.81$ years. There was no statistically significant difference in the duration of surgery in the three groups $(\mathrm{P}=0.679)$.

According to Table 2, there was no significant difference in age between the three groups $(\mathrm{P}=0.783)$.

As shown in Table3, there was no significant difference in gender in the four groups $(\mathrm{P}=0.358)$. Laparoscopic surgery is more common in women than in men, as known from previous studies.

As shown in Table 4 and Figure 1, there was a statistically significant difference in blood pressure at all times except at baseline in the three groups $(\mathrm{P}<0.05)$. Blood pressure was lower in the dexmedetomidine group at all times. Subsequently, the drug combination group had lower blood pressure than the dexamethasone group.

Table 2. Comparison of mean and standard deviation of age in dexamethasone, dexmedetomidine and drug combination groups.

\begin{tabular}{|c|c|c|c|c|}
\hline $\begin{array}{l}\quad \text { Group } \\
\text { Quantitative } \\
\text { variable }\end{array}$ & $\begin{array}{l}\text { Drug combination } \\
\text { Mean } \pm S D\end{array}$ & $\begin{array}{c}\text { Dexmedetomidine } \\
\text { Mean } \pm S D\end{array}$ & $\begin{array}{c}\text { Dexamethasone } \\
\text { Mean } \pm S D\end{array}$ & P-value \\
\hline Age & $49.01 \pm 7.02$ & $49.00 \pm 7.80$ & $49.92 \pm 8.65$ & 0.783 \\
\hline
\end{tabular}

Table 3. Comparison of frequency and sex in dexamethasone, dexmedetomidine and drug combination groups.

\begin{tabular}{|c|c|c|c|c|}
\hline Gender Group & Drug combination (\%)n & Dexmedetomidine (\%)n & Dexamethasone (\%)n & P-value \\
\hline Female & $43(79.62)$ & $48(88.88)$ & $47(87.03)$ & \multirow{2}{*}{0.358} \\
\hline Male & $11(20.37)$ & $6(11.11)$ & 7 (12.96) & \\
\hline
\end{tabular}

\begin{tabular}{|c|c|c|c|c|}
\hline Group & $\begin{array}{l}\text { Drug combination } \\
\text { Mean } \pm S D\end{array}$ & $\begin{array}{l}\text { Dexmedetomidine } \\
\text { Mean } \pm \text { SD }\end{array}$ & $\begin{array}{l}\text { Dexamethasone } \\
\text { Mean } \pm \text { SD }\end{array}$ & P-value \\
\hline Initiation & $84.25 \pm 7.46$ & $85.98 \pm 7.17$ & $86.53 \pm 7.62$ & 0.254 \\
\hline $\begin{array}{l}15 \text { minutes after surgery } \\
\text { initiation }\end{array}$ & $79.66 \pm 6.90$ & $76.22 \pm 4.63$ & $82.25 \pm 7.02$ & 0.0001 \\
\hline $\begin{array}{l}30 \text { minutes after surgery } \\
\text { initiation }\end{array}$ & $79.11 \pm 7.94$ & $73.25 \pm 4.80$ & $83.66 \pm 6.11$ & 0.0001 \\
\hline $\begin{array}{l}45 \text { minutes after surgery } \\
\text { initiation }\end{array}$ & $77.00 \pm 7.95$ & $70.74 \pm 3.62$ & $82.29 \pm 6.11$ & 0.0001 \\
\hline $\begin{array}{l}60 \text { minutes after surgery } \\
\text { initiation }\end{array}$ & $77.38 \pm 8.89$ & $69.50 \pm 4.58$ & $83.55 \pm 5.34$ & 0.0001 \\
\hline $\begin{array}{l}75 \text { minutes after surgery } \\
\text { initiation }\end{array}$ & $76.75 \pm 8.19$ & $70.35 \pm 5.37$ & $82.61 \pm 4.91$ & 0.0001 \\
\hline $\begin{array}{l}90 \text { minutes after surgery } \\
\text { initiation }\end{array}$ & $77.14 \pm 7.35$ & $70.75 \pm 5.10$ & $82.68 \pm 3.98$ & 0.0001 \\
\hline $\begin{array}{l}105 \text { minutes after } \\
\text { surgery initiation }\end{array}$ & $78.57 \pm 8.77$ & $71.16 \pm 5.56$ & $85.14 \pm 3.72$ & 0.0001 \\
\hline
\end{tabular}




\section{JOURNAL of MEDICINE and LIFE}

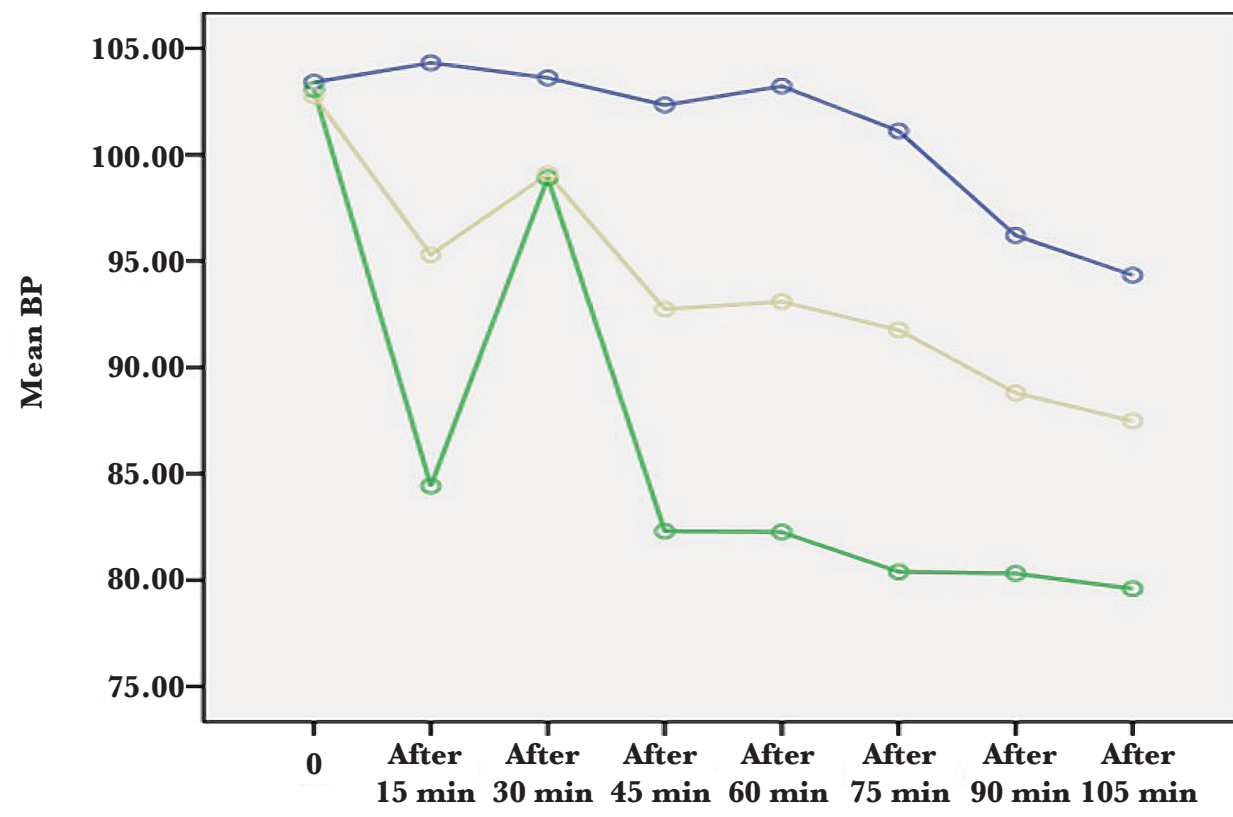

Dexamethasone

Dexamedetomidine

Dexamethasone \&

Dexamedetomidine

(After initiation of surgery)

Figure 1. Comparison of mean blood pressure in dexamethasone, dexmedetomidine and drug combination groups.

Heart rate at all times was statistically significant between the three groups except at baseline $(\mathrm{P}<0.05)$. The lowest heart rate was seen in the dexmedetomidine group. After dexmedetomidine, the drug combination group had a lower heart rate than the dexamethasone group (Table 5, Figure 2) However, as seen in Table 6 and Figure 3, there was no statistically significant difference in the percentage of oxygen saturation at all times $(\mathrm{P}>0.05)$.

There was no statistically significant difference regarding vomiting in recovery and 4 hours after surgery in the three groups $(\mathrm{P}>0.05)$ (Table 7). A significant difference was observed 2 hours after surgery $(\mathrm{p}=0.012)$. In the combination group of dexamethasone and dexmedetomidine, vomiting was less frequently reported compared to the other groups.

Table 5. Comparison of mean and standard deviation of heart rate in dexamethasone, dexmedetomidine and drug combination groups.

\begin{tabular}{|l|c|c|c|c|}
\hline Group Heart rate & $\begin{array}{c}\text { Drug combination } \\
\text { Mean } \pm \text { SD }\end{array}$ & $\begin{array}{c}\text { Dexmedetomidine } \\
\text { Mean } \pm \text { SD }\end{array}$ & $\begin{array}{c}\text { Dexamethasone } \\
\text { Mean } \pm \text { SD }\end{array}$ & P-value \\
\hline Initiation & $92.77 \pm 5.58$ & $93.05 \pm 3.30$ & $93.40 \pm 5.44$ & 0.799 \\
\hline $\begin{array}{l}\mathbf{1 5} \text { minutes after surgery } \\
\text { initiation }\end{array}$ & $85.29 \pm 11.85$ & $74.42 \pm 9.04$ & $94.31 \pm 4.29$ & 0.0001 \\
\hline $\begin{array}{l}\mathbf{3 0} \text { minutes after surgery } \\
\text { initiation }\end{array}$ & $89.09 \pm 5.52$ & $88.90 \pm 6.15$ & $93.61 \pm 4.52$ & 0.0001 \\
\hline $\begin{array}{l}\mathbf{4 5} \text { minutes after surgery } \\
\text { initiation }\end{array}$ & $82.74 \pm 12.20$ & $72.29 \pm 9.33$ & $92.33 \pm 3.81$ & 0.014 \\
\hline $\begin{array}{l}\mathbf{6 0} \text { minutes after surgery } \\
\text { initiation }\end{array}$ & $83.09 \pm 12.64$ & $72.25 \pm 9.45$ & $93.22 \pm 3.55$ & 0.0001 \\
\hline $\begin{array}{l}\mathbf{7 5} \text { minutes after surgery } \\
\text { initiation }\end{array}$ & $81.75 \pm 11.78$ & $70.38 \pm 8.18$ & $91.11 \pm 3.79$ & 0.0001 \\
\hline $\begin{array}{l}\mathbf{9 0} \text { minutes after surgery } \\
\text { initiation }\end{array}$ & $78.79 \pm 9.75$ & $70.31 \pm 7.46$ & $86.20 \pm 3.95$ & 0.0001 \\
\hline $\begin{array}{l}\mathbf{1 0 5} \text { minutes after } \\
\text { surgery initiation }\end{array}$ & $77.48 \pm 9.68$ & $69.59 \pm 8.94$ & $84.33 \pm 3.66$ & \\
\hline
\end{tabular}




\section{JOURNAL of MEDICINE and LIFE}

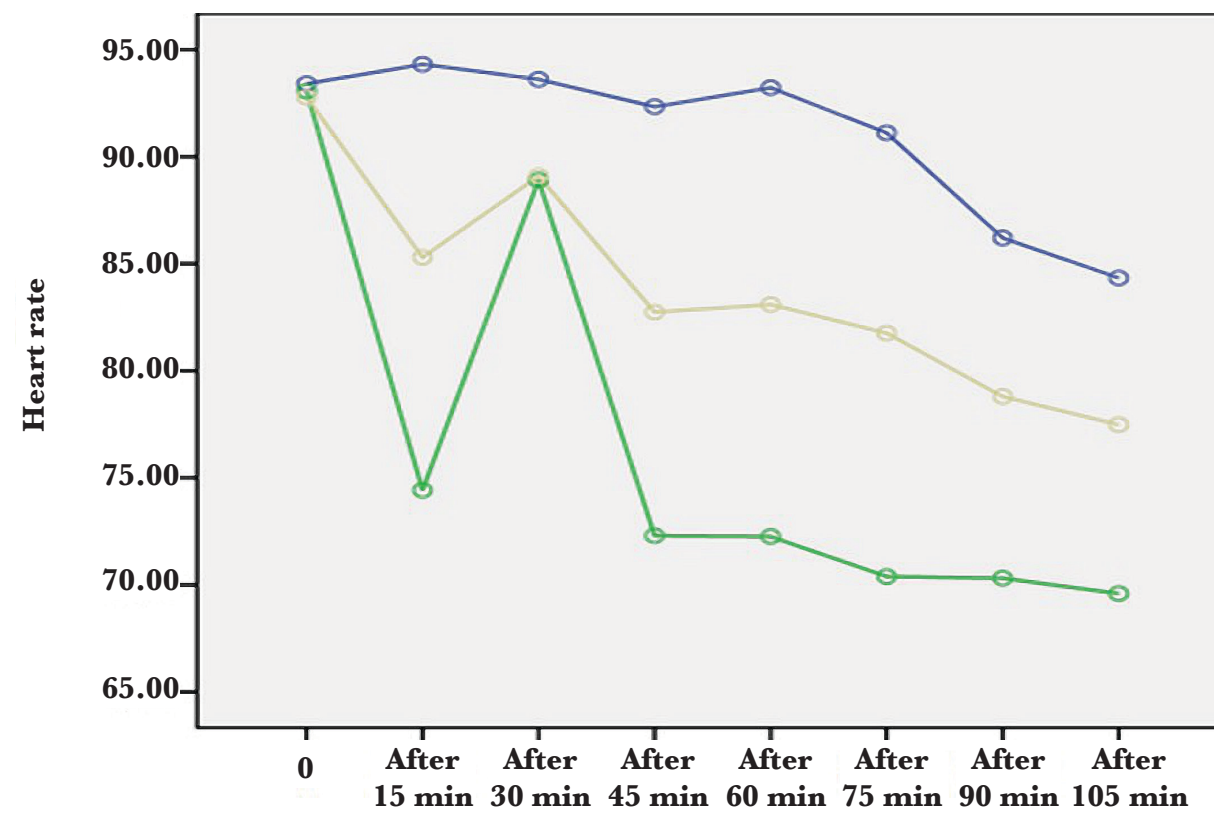

- Dexamethasone

—- Dexamedetomidine

Dexamethasone \&

Dexamedetomidine

(After initiation of surgery)

Figure 2. Comparison of mean heart rate in dexamethasone, dexmedetomidine and drug combination groups.

The incidence of nausea during recovery was not significantly different between the three groups $(\mathrm{P}>0.05)$. The incidence of nausea at 2 and 4 hours after surgery was statistically significant between the three groups $(\mathrm{P}<0.05)$, being lower in the combination group (dexamethasone and dexmedetomidine) compared to the other two groups (Table 8).

\section{DISCUSSION}

The purpose of this study was to compare the prophylactic effect of dexamethasone and dexmedetomidine and the combination of both in reducing postoperative nausea and vomiting in patients undergoing laparoscopic cholecystitis. The number of women in this study was higher, which is in line with the high prevalence of laparoscopic surgery in women.

We found that blood pressure was lower in the dexmedetomidine group at all times. In the next step, the combination of the two drugs showed lower blood pressure than the dexamethasone group. The lowest heart rate was seen in the dexmedetomidine group. After dexmedetomidine, the combination group had a lower heart rate compared to the dexamethasone group. Two hours after surgery, the vomiting was less frequent in the combination group. The incidence of nausea at 2 and 4 hours after surgery was lower in the dexamethasone and dexmedetomidine combination group than in the other two groups. Dexmedetomidine is one of the potent alpha-2-adrenergic receptor agonists that have been widely used due to its anxiolytic, sedative, analgesic, sympatholytic and hemodynamic regulation properties [9].

During surgery, dexmedetomidine can reduce the incidence of restlessness and provide an acceptable recovery. It also reduces postoperative pain without hemodynamic complications so that it can prevent postoperative nausea and vomiting [9]. The anti-nausea and vomiting effect of low-dose dexmedetomidine in reducing postoperative nausea and vomiting has been proven in numerous studies [10-12]. In our study, the combination between dexmedetomidine and dexamethasone decreased postoperative nausea and vomiting and decreased more significantly blood pressure and heart rate compared to the agents given alone.

In 2017, Shenhui et al. conducted a review to evaluate the role of dexmedetomidine in preventing nausea and vomiting in general anesthesia. The authors suggested that it could be used to reduce nausea and vomiting if the dexmedetomidine side effects could be reduced [24] and their results were in line with our study. Kleif et al. also conducted a study aimed to define the effect of preoperative dexamethasone on postoperative nausea and vomiting. Nausea and vomiting were assessed on the first postoperative day, and 120 patients were enrolled. They stated that dexamethasone did not reduce nausea and vomiting [25]. In our study, the combination between dexamethasone and dexmedetomidine reduced postoperative nausea and vomiting. Geng et al. studied the effect of dexmedetomidine on 65 adults undergoing laparoscopic surgery with $0.5 \mathrm{mg} / \mathrm{kg}$ dexmedetomidine before anesthesia until the end of the surgery, and they found that dexmedetomidine reduced postoperative nausea but had no effect on vomiting 24 hours after surgery [26]. In our 


\section{JOURNAL of MEDICINE and LIFE}

Table 6. Comparison of mean and standard deviation of oxygen saturation percentage in dexamethasone, dexmedetomidine and drug combination groups.

\begin{tabular}{|c|c|c|c|c|}
\hline Group Oxygen saturation & $\begin{array}{l}\text { Dexamethasone } \\
\text { Mean } \pm \text { SD }\end{array}$ & $\begin{array}{l}\text { Dexmedetomidine } \\
\text { Mean } \pm \text { SD }\end{array}$ & $\begin{array}{l}\text { Drug combination } \\
\text { Mean } \pm S D\end{array}$ & P-value \\
\hline Initiation & $96.35 \pm 0.587$ & $96.33 \pm 0.614$ & $96.35 \pm 0.587$ & 0.983 \\
\hline $\begin{array}{l}15 \text { minutes after surgery } \\
\text { initiation }\end{array}$ & $96.48 \pm 0.74$ & $96.48 \pm 0.745$ & $96.46 \pm 0.745$ & 0.989 \\
\hline $\begin{array}{l}30 \text { minutes after surgery } \\
\text { initiation }\end{array}$ & $98.59 \pm 0.714$ & $96.79 \pm 0.6555$ & $96.77 \pm 1.609$ & 0.560 \\
\hline $\begin{array}{l}45 \text { minutes after surgery } \\
\text { initiation }\end{array}$ & $96.59 \pm 0.789$ & $96.29 \pm 0.964$ & $96.35 \pm 0.827$ & 0.169 \\
\hline $\begin{array}{l}60 \text { minutes after surgery } \\
\text { initiation }\end{array}$ & $96.75 \pm 0.547$ & $96.90 \pm 0.783$ & $97.18 \pm 1.93$ & 0.200 \\
\hline $\begin{array}{l}75 \text { minutes after surgery } \\
\text { initiation }\end{array}$ & $96.55 \pm 0.603$ & $96.48 \pm 0.665$ & $96.20 \pm 1.64$ & 0.835 \\
\hline $\begin{array}{l}90 \text { minutes after surgery } \\
\text { initiation }\end{array}$ & $97.42 \pm 0.716$ & $97.48 \pm 1.023$ & $97.74 \pm 0.974$ & 0.210 \\
\hline $\begin{array}{l}105 \text { minutes after } \\
\text { surgery initiation }\end{array}$ & $97.16 \pm 0636$ & $97.00 \pm 0.582$ & $96.94 \pm 0.563$ & 0.165 \\
\hline
\end{tabular}

study, a combination of dexamethasone and dexmedetomidine reduced postoperative nausea and vomiting. In our study, however, nausea and vomiting were assessed up to 4 hours postoperatively. In 2015, Bakri et al. performed a study on 86 patients in Sudan entitled "Comparing dexmedetomidine and dexamethasone in preventing nausea and vomiting after laparoscopic cholecystectomy". The authors showed that dexmedetomidine reduced the severity and incidence of postoperative nausea and vomiting as the patients in the dexmedetomidine group had less pain in the first 24 hours after surgery [27]. In our study, the combination between dexamethasone

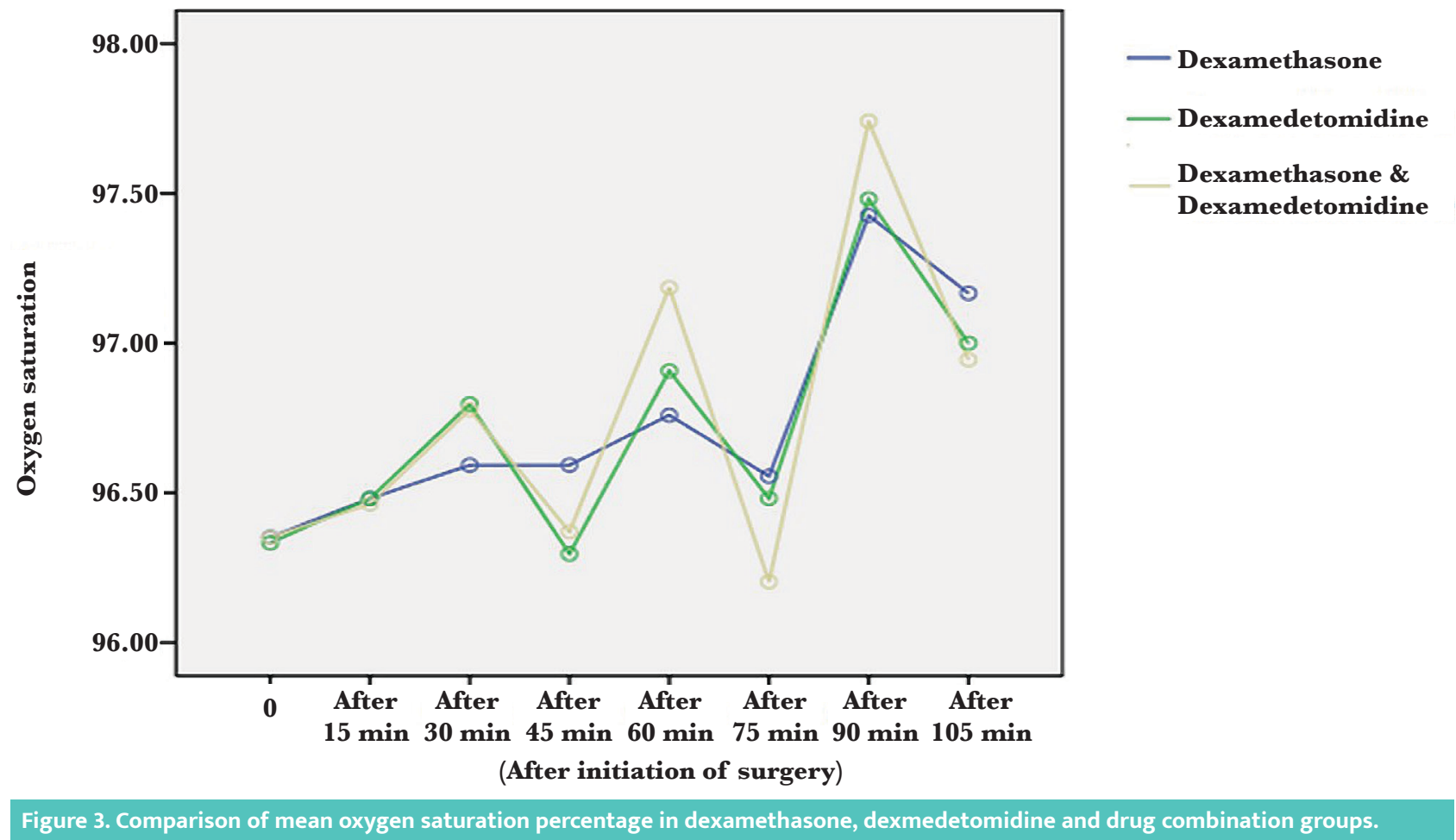




\section{JOURNAL of MEDICINE and LIFE}

Table 7. Comparison of mean and standard deviation of vomiting in dexamethasone, dexmedetomidine and drug combination groups.

\begin{tabular}{|c|c|c|c|c|}
\hline Vomiting Group & $\begin{array}{l}\text { Dexamethasone } \\
\text { Mean } \pm S D\end{array}$ & $\begin{array}{c}\text { Dexmedetomidine } \\
\text { Mean } \pm S D\end{array}$ & $\begin{array}{l}\text { Drug combination } \\
\text { Mean } \pm S D\end{array}$ & P-value \\
\hline Recovery & $0.562 \pm 0.203$ & $0.419 \pm 0.222$ & $0.264 \pm 0.074$ & 0.156 \\
\hline $\begin{array}{l}2 \text { hour after surgery } \\
\text { termination }\end{array}$ & $0.406 \pm 0.203$ & $0.460 \pm 0.296$ & $0.264 \pm 0.074$ & 0.012 \\
\hline $\begin{array}{l}4 \text { hour after surgery } \\
\text { termination }\end{array}$ & $0.406 \pm 0.203$ & $0.358 \pm 0.148$ & $0.264 \pm 0.074$ & 0.155 \\
\hline
\end{tabular}

Table 8. Comparison of frequency and incidence of nausea in dexamethasone, dexmedetomidine and drug combination groups.

\begin{tabular}{|c|c|c|c|c|c|}
\hline \multicolumn{2}{|l|}{ Nausea Group } & $\begin{array}{c}\text { Dexamethasone } \\
\text { Mean } \pm S D\end{array}$ & $\begin{array}{l}\text { Dexmedetomidine } \\
\text { Mean } \pm S D\end{array}$ & $\begin{array}{l}\text { Drug combination } \\
\text { Mean } \pm S D\end{array}$ & P-value \\
\hline \multirow{3}{*}{ Recovery } & Yes & 11 & 14 & 12 & \multirow{3}{*}{0.783} \\
\hline & & & & & \\
\hline & No & 43 & 40 & 42 & \\
\hline \multirow{2}{*}{$\begin{array}{l}2 \text { hours after } \\
\text { surgery termination }\end{array}$} & Yes & 15 & 20 & 8 & \multirow{2}{*}{0.032} \\
\hline & No & 39 & 34 & 46 & \\
\hline \multirow{2}{*}{$\begin{array}{l}4 \text { hours after } \\
\text { surgery termination }\end{array}$} & Yes & 11 & 20 & 8 & \multirow{2}{*}{0.019} \\
\hline & No & 43 & 34 & 46 & \\
\hline
\end{tabular}

and dexmedetomidine reduced postoperative nausea and vomiting. In a meta-analysis from 2015, Liang et al. studied the effect of dexmedetomidine on postoperative PONV, using data from Pubmed and Embase databases in a study of 6480 patients, and found that dexmedetomidine had a greater effect on PONV inhibition than placebo, but could not cover all post-anesthetic complications [28]. In our study, the combination of dexamethasone and dexmedetomidine reduced the incidence of postoperative nausea and vomiting. In their study from 2010 performed on 50 patients, Banihashem et al. found that dexamethasone and ondansetron reduced the incidence of nausea, vomiting, and itching of intrathecal meperidine in women undergoing elective cesarean section [29].

In our study, the combination of dexamethasone and dexmedetomidine reduced the incidence of postoperative nausea and vomiting. Blood pressure and heart rate values were lower in the dexmedetomidine group at all times and the combination group compared to the dexamethasone group. The combination of dexmedetomidine and dexamethasone reduced postoperative nausea and vomiting in patients. However, further studies with larger sample sizes are recommended, and it is worthy of considering that nausea and vomiting may be recorded starting from 24 hours postoperatively.

\section{ACKNOWLEDGMENTS}

This manuscript is the result of Dr. Rakei's PhD thesis. We are grateful for the guidance of the Clinical Research Council of Valiasr Hospital and the honorable vice-chancellor for research of Arak University of Medical Sciences.

\section{Ethical approval}

The approval for this study was obtained from the Ethics Committee of the Arak University of Medical Sciences (approval ID: IR.ARAKMU.REG.1397.309 from 01/22/2019). The clinical trial code is IRCT20141209020258N100.

\section{Consent to participate}

Written informed consent was obtained from the participants.

\section{Conflict of interest}

The authors declare that there is no conflict of interest. 


\section{JOURNAL of MEDICINE and LIFE}

\section{REFERENCES}

1. Apfel C. et al. A simplified risk score for predicting postoperative nausea and vomiting: conclusions from cross-validations between two centers. Anesthesiology, 1999. 91: p. 693-700.

2. McCracken G., P. Houston and G. Lefebvre Guideline for the Management of Postoperative Nausea and Vomiting. July Jogc Juillet 2008(209).

3. Schumann R. and D.M. Polaner, Massive subcutaneous emphysema and sudden airway compromise after postoperative vomiting. Anesth Analg, 1999. 89(3): p. 796-7.

4. Bremner W.G. and C.M. Kumar, Delayed surgical emphysema, pneumomediastinum and bilateral pneumothoraces after postoperative vomiting. Br J Anaesth, 1993. 71(2): p. 296-7.

5. Balki M. and J.C. Carvalho, Intraoperative nausea and vomiting during cesarean section under regional anesthesia Int J Obstet Anesth, 2005. 14(3): p. 230-41.

6. Mishriky B.M. and A.S. Habib, Metoclopramide for nausea and vomiting prophylaxis during and after Caesarean delivery: a systematic review and meta-analysis. Br J Anaesth, 2012. 108(3): p. 374-83.

7. Griffiths J.D. et al., Interventions for preventing nausea and vomiting in women undergoing regional anaesthesia for caesarean section. Cochrane Database Syst Rev, 2012. 9: p. CD007579.

8. Masters S., A. Trevor, and B. Katzung Basic \& Clinical Pharmacology. 2009: Arjmand.

9. Gupta, N. et al., Effect of intraoperative dexmedetomidine on postoperative recovery profile of children undergoing surgery for spinal dysraphism. J Neurosurg Anesthesiol, 2013. 25(3): p. 271-8.

10. Massad I.M. et al., A balanced anesthesia with dexmedetomidine decreases postoperative nausea and vomiting after laparoscopic surgery. Saudi Med J, 2009. 30(12): p. 1537-41.

11. Abdelmageed W.M., et al. Analgesic properties of a dexmedetomidine infusion after uvulopalatopharyngoplasty in patients with obstructive sleep apnea. Saudi J Anaesth, 2011. 5(2): p. $150-6$.

12. Goksu S. et al. Effects of dexmedetomidine infusion in patients undergoing functional endoscopic sinus surgery under local anaesthesia. Eur J Anaesthesiol, 2008. 25(1): p. 22-8.

13. Gudarzi M. M. Marla, and M. Matar A prospective randomized blind study of the effect of IV fluid therapy on PONV in children undergoing strabismus surgery. Pediatric Anesthesia 2005. 16: p. 49-53.

14. Habib M. and S. Ashrof A randomized comparison of multimodal management strategy vs combination antiemetic for the Prevention of PONV. Anesthesia Analgesia 2004. 99(1): p. $77-81$.

15. Elhakim M. and N. Ali Dexamethason reduce postoperative vomiting and pain after tonsillectomy. Can J Anaesth 2003. 50(4): p. 392-7.

16. Henzi I. B. Walder and M. Tramer Dexamethasone for the prevention of past operative nausea and vomiting. Aresth Analg, 2000. 90: p. 186

17. Wang J. et al. The prophylactic effect of dexamethasone on postoperative nausea and vomiting in women undergoing thyroidectomy: a comparison of droperidol with saline. Anesth Analg, 1999. 89: p. 200-3.

18. Fujii Y. et al. Granisetron/dexamethasone combination for reducing nausea and vomiting during and after spinal anesthesia for cesarean section. Anesth Analg, 1999. 88: p. $1346-50$.

19. Chen M. et al. Dexamethasone effectively reduces postoperative nausea and vomiting in a general surgical adult patient population. Chang Gung

Med J 2006. 29(2): p. 175-81.

20. Madan R. et al. Prophylactic dexamethasone for postoperative nausea and vomiting in pediatric strabismus surgery: a dose ranging and safety evaluation study. Anesth Analg, 2005. 100(6): p. 1622-6.

21. Nortcliffe S., J. Shah and D. Buggy Prevention of postoperative nausea and vomiting after spinal morphine for
Caesarean section: comparison of cyclizine, dexamethasone and placebo. Br J Anaesth, 2003. 90(5): p. 665-70.

22. Fujii Y., Prevention of emetic episodes during cesarean delivery performed under regional anesthesia in parturients. Curr Drug Saf, 2007. 2(1): p. 25-32.

23. Harnett M.J. et al. Transdermal scopolamine for prevention of intrathecal morphine-induced nausea and vomiting after cesarean delivery. Anesth Analg, 2007. 105(3): p. 764-9.

24. Shenhui J. et al. Dexmedetomidine prevent postoperative nausa and vomiting on patients during general anesthesia. Medicine, 2017. 96(1): p. 5770.

25. Kleif J. et al. Randomize clinical trials of post operative dexametasone on postoperative nausa and vomitting after laparoscopy for suspected appendicitis. British Journal of surgery, 2017. 104(4): p. 384-392.

26. Geng Z. et al. Intra-operative dexmedetomidine reduces early postoperative nausea but not vomiting in adult patient after gynecological laparoscopic surgery: A randomised controlled trial. European Journal of Anesthesiology, 2016. 33(10): p. 761-766.

27. Bakri, M.H., E.A. Ismail, and A. Ibrahim, Comparison of dexmedetomidine and dexamethasone for prevention of postoperative nausea and vomiting after laparoscopic cholecystectomy. Korean J Anesthesiol, 2015. 68(3): p. 254-60.

28. Liang X. Efficacy of dexmedetomidine on postoperative nausea and vomiting: a meta-analysis of randomized controlled trials. Int J Clin Exp Med, 2015. 8(6): p. 8450-8471.

29. Banihashem N. et al. Comparison of the prophylactic effect of ondansetron and dexamethasone on postoperative nausea and vomiting after intrathecal meperidine in women scheduled for elective cesarean section.J Babol Univ Med Sci, 2011. 13(3): p. 29-33. 